\title{
In Vitro Study of MefenamateStarch as Drug Delivery System
}

\author{
Firyal M. Ali * \\ Firas A. Rahi ** \\ Aseel Q. M** \\ Huda M. A**
}

Received 12, November, 2012

Accepted 17, December, 2012

\begin{abstract}
:
Mefenamic acid was esterified with starchwith[1:1] Molar ratio, as drug substituted with natural polymer, to prolongthe period of hydrolysis of drug polymer with other advantages. The new prodrug starch was characterized by FT-IR and UVVisible and ${ }^{1} \mathrm{H}$-NMR spectroscopies. The physical properties were studied and controlled drug release was studied in different $\mathrm{pH}$ values at $37^{\circ} \mathrm{C}$. The stability of drug was carried out by measuring the absorbance of mefenamic starch which hydrolyzed in $\mathrm{HCl}$ solution of $\mathrm{pH} 1.1$ (artificial gastric fluid) and phosphate buffer of $\mathrm{pH} 7.4$ (simulating intestinal fluid SIF) at $37^{\circ} \mathrm{C}$ for several days. The thermal analysis such as DSC was studied.
\end{abstract}

Key words: Mefenamic acid, Starch, natural polymers, esterfication

\section{Introduction}

The action of polymeric drugs in vivo usually depends on hydrolytic on enzymatic cleavage of the drug moiety from the polymer $[1,2]$, this give advantage of delayed and sustained release of drug over long time with corresponding decrease of side effects [3]. It is potentially possible to make a polymer drug with specific required solubility rate of diffusion and increased or decreased activity by the appropriate choice of the polymer and the drug. These include situation requiring the slow release of water-soluble drugs, the fast release is of the low solubility drugs [4].

Poly (Vinyl Alcohol) is almost completely resistant to fungi and bacteria in dry state. Aqueous solutions are susceptible to microbial degradation [5]. In these systems, the drug molecule is chemically bonded to a polymer backbone and the drug released approach provides an opportunity to target the drug to a particular cell type or tissue affinity [6, 7].

Mefenamic acid is a nonsteriodal anti-inflammatory drug used to treat pain, including menstrpain [8]. The side effects of the mefenamic acid include headache, nervousness, vomiting, diarrhea, hematemesis (blood urine), skin rash and swelling $[9,10]$.

Cell immobilization by means of biomass entrapment [11] within 
various hydrogels is one of the progressive approaches, for the creation of immobilized biocatalyst $[12,13]$. Many diverse gel matrices have been proposed as possible carriers. In these cases, ether natural biopolymers (polysaccharides such as aliginate, carrageenan, agar, ...etc. or proteins such as gelatin collagen and others) or synthetic polymers (polyacrylate, polyurethanes and polyethers) can be used as the gelforming agent.

\section{Materials and Methods:}

\section{Materials :}

Mefenamic acid was obtained from Pharmacy College, starch, dioxand, DMF and ether were purchased from Fluka.

\section{Synthesis of Starch-Mefenamate :}

In a $(100 \mathrm{ml})$ round bottom flask provided with magnetic bar was introduced (5 g., 0.025 mole) of starch with $15 \mathrm{ml}$ of dioxin, the prepared mefenamic acid chloride was added ( g., 0.025 mole) with vigorous stirring, the mixture was refluxed for about 1 hr. the precipitate was filtered and then washed with ether for several times and the product was dried.

Table (1): The Physical Properties of StarchMefenamate

\begin{tabular}{|c|c|c|c|c|c|}
\hline No. & Color & $\begin{array}{c}\text { Softening } \\
\text { Point }^{\mathbf{}} \mathbf{C}\end{array}$ & $\begin{array}{c}\text { UV. } \\
\text { Absorption } \\
\mathbf{n m}\end{array}$ & $\begin{array}{c}\text { Conversion } \\
\boldsymbol{\%}\end{array}$ & $\boldsymbol{\Delta} \mathbf{H ~ J / g}$ \\
\hline $\mathrm{P}_{1}$ & Brown & 283.38 & $280-330$ & 80 & 190.9 \\
\hline
\end{tabular}

\section{Controlled Drug Release :}

$(0.1 \mathrm{~g})$ of the prepared starchdrug $\mathrm{P}_{1}$ was placed in $50 \mathrm{ml}$ of buffer solution with $\mathrm{pH} 1.1$ or 7.4 at $37^{\circ} \mathrm{C}$. At periodic intervals $2 \mathrm{ml}$ of solution with tested at 280nm using UV. Spectrophotometer. The amount of the released mefenamic acid was quantified using appropriate calibration curve and figure 3 shows the mole fraction of drug release through many days.

\section{Results and Discussion}

The formula of mefenamic acid is $\mathrm{C}_{15} \mathrm{H}_{15} \mathrm{NO}_{2}$ its structure is as shown :

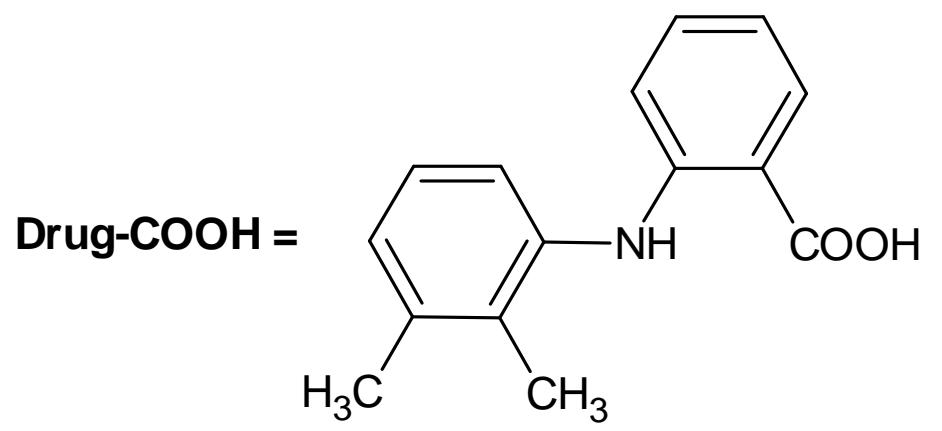

2-(2,3-dimethyl phenyl) aminobenzoic acid mol. mass 241 
The acid chloride-drug was bonded with starch by esterification reaction with 1:1 molar ratio according to the following reaction:

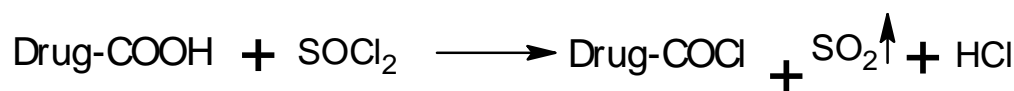

Starch-OH + Drug-COCl

The modified starch which is bonded with drug; this polymer has been investigated in this study, using FT-IR spectrum, figure 1 of the blank sample and figure 2 of drug bonded polymer reveals the existence of peaks at 3311 and $2980 \mathrm{~cm}^{-1}$, which are due to $-\mathrm{NH}$ of mefenamateand $\mathrm{C}-\mathrm{H}$ stretching of methyl groups, respectively, the $v \mathrm{C}=\mathrm{O}$ absorption was observed at $1668 \mathrm{~cm}^{-1}$ of ester group, these peaks confirm the polymer formation. The presence of the drug in the polymer is confirmed by the fact that peaks in the rang $3100 \mathrm{~cm}^{-1}$ due to $\mathrm{C}-\mathrm{H}$ stretching of aromatic groups appear in the spectrum of both blank and drug bonded polymer sample; the aromatic $\mathrm{C}-\mathrm{H}$ and out-of-plane peaks

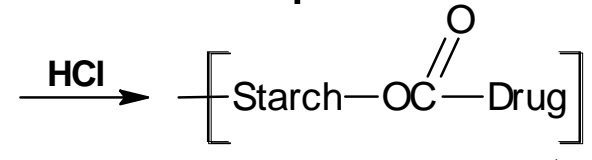

appear at $900-700 \mathrm{~cm}^{-1}$, and $\mathrm{C}=\mathrm{C}$ streatching appears at $1600 \mathrm{~cm}^{-1}$ in both spectra. Also, the remained $\mathrm{OH}$ starch have been observed at $3450 \mathrm{~cm}^{-}$ 1 .

The conventional controlled release dosage form is the inability to increase its residence time for example in $\mathrm{pH} 1.1$ of small intestine, resulting in an improved and bioavailability of the basic drug and to prolong the presences of dosage form in the stomach until all the drug is released in the desired period of time, figure (3) shows the controlled drug release in different $\mathrm{pH}$ values at $37^{\circ} \mathrm{C}$, and the following equation shows the hydrolysis of drug bonded polymer through ester:

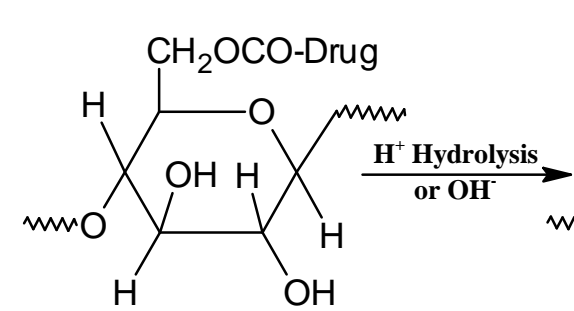

The amount of drug released was determined spectrophotometrically, the total volume of release medium was kept constant by addition of the drawal sample every time.

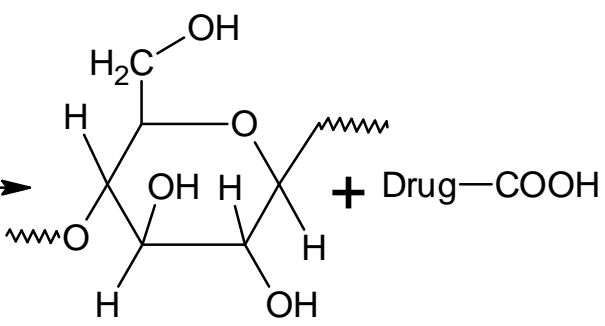

The hydrolysis of ester group in acidic medium was lower than alkalinmedium, this was attributed to attack $\mathrm{OH}^{-}$as nucleophilic to carbonyl group. The mechanism is illustrated as shown below

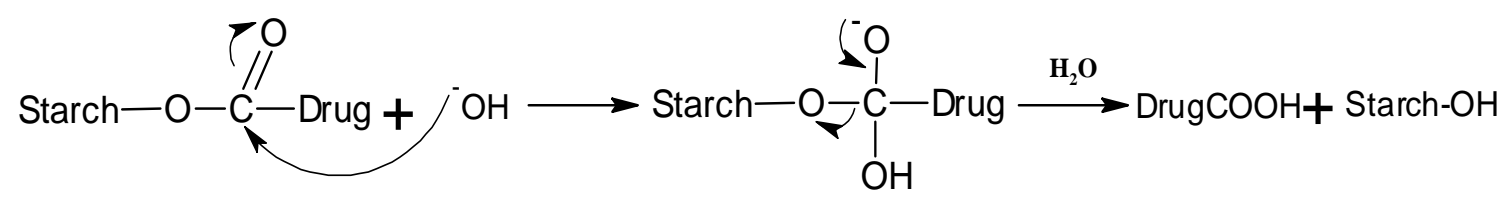


This study of the drug elution with time evidence that only a fraction of the total amount of the initially adsorbed drug is released and the eluted amount depends on the strength of the drug-polymer interaction and the ester group was observed as a good hydrolysis through basic medium.

The present paper aimed at developing drug-polymer models able to prevent infections associated with the use of medical devices. The drugpolymer possessing long-term drug activity, which is hydrolyzed gradually in specific site, in suitable $\mathrm{pH}$ values. Also, we aimed in this paper to use natural polymer such as starch to prevent any toxicity or any side effect.

The natural drug-polymer plays a significant role, in fact, high specificity of interaction together.

$$
\Delta_{m}=\frac{m_{1}-m_{0}}{m_{0}} * 100
$$

Where, $\quad \mathrm{m}_{0}$ is the mass of a dry polymer at $\mathrm{t}=0$

$m_{1}$ is the swallowed

polymer at time $t$.

\section{Swelling Behavior:}

In order to study the swelling behavior $0.05 \mathrm{~g}$ of the sample was immersed in water as swelling solution and the weight of the swollen sample was measured against time after the excess surface water was removed by gently tapping the surface with a drug pieces of filter paper. The degree of swelling was calculated using the following equation:

it appears that high swelling\% was obtained for the prepared drug polymer through $1 \mathrm{hr}$. 


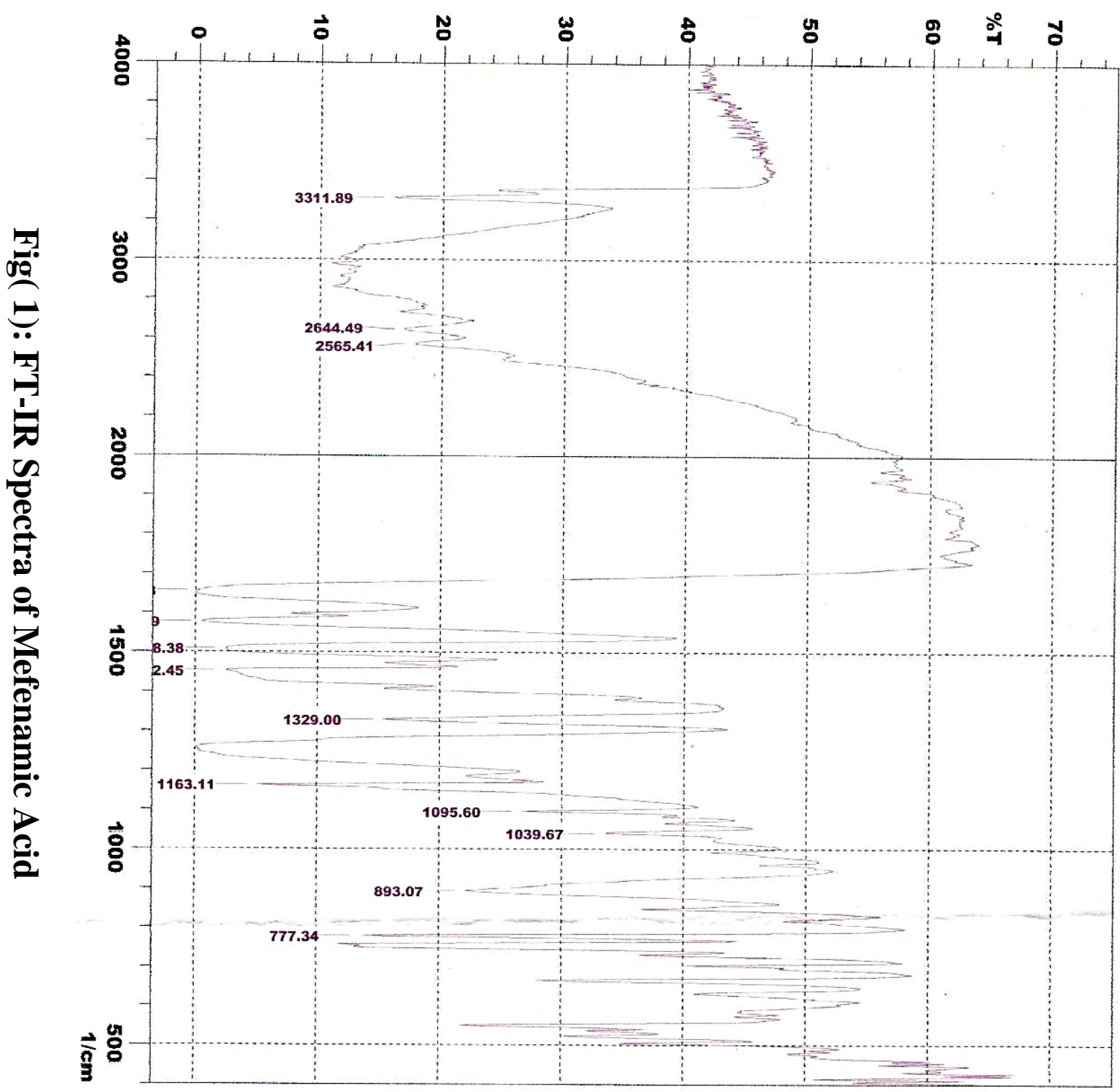




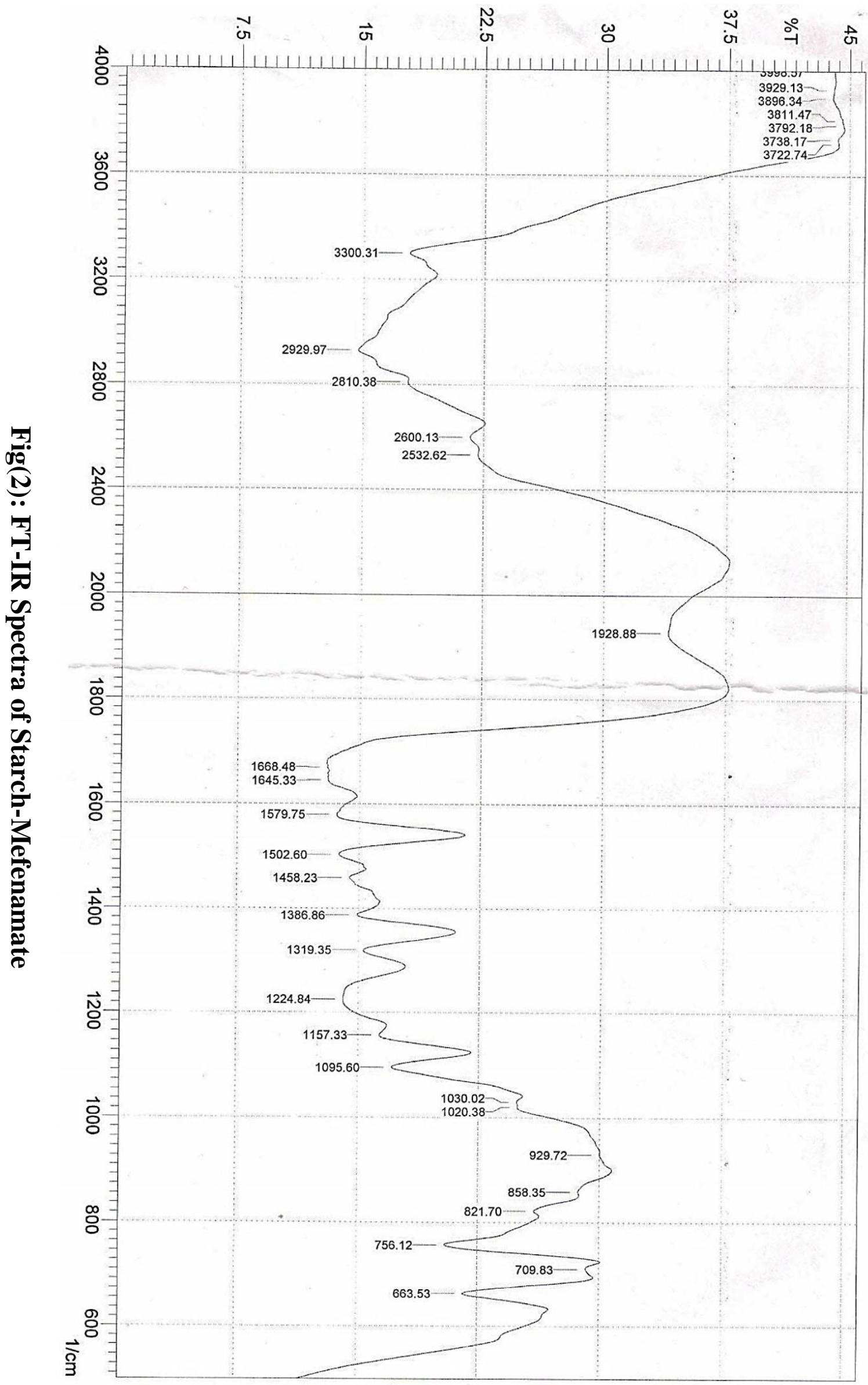




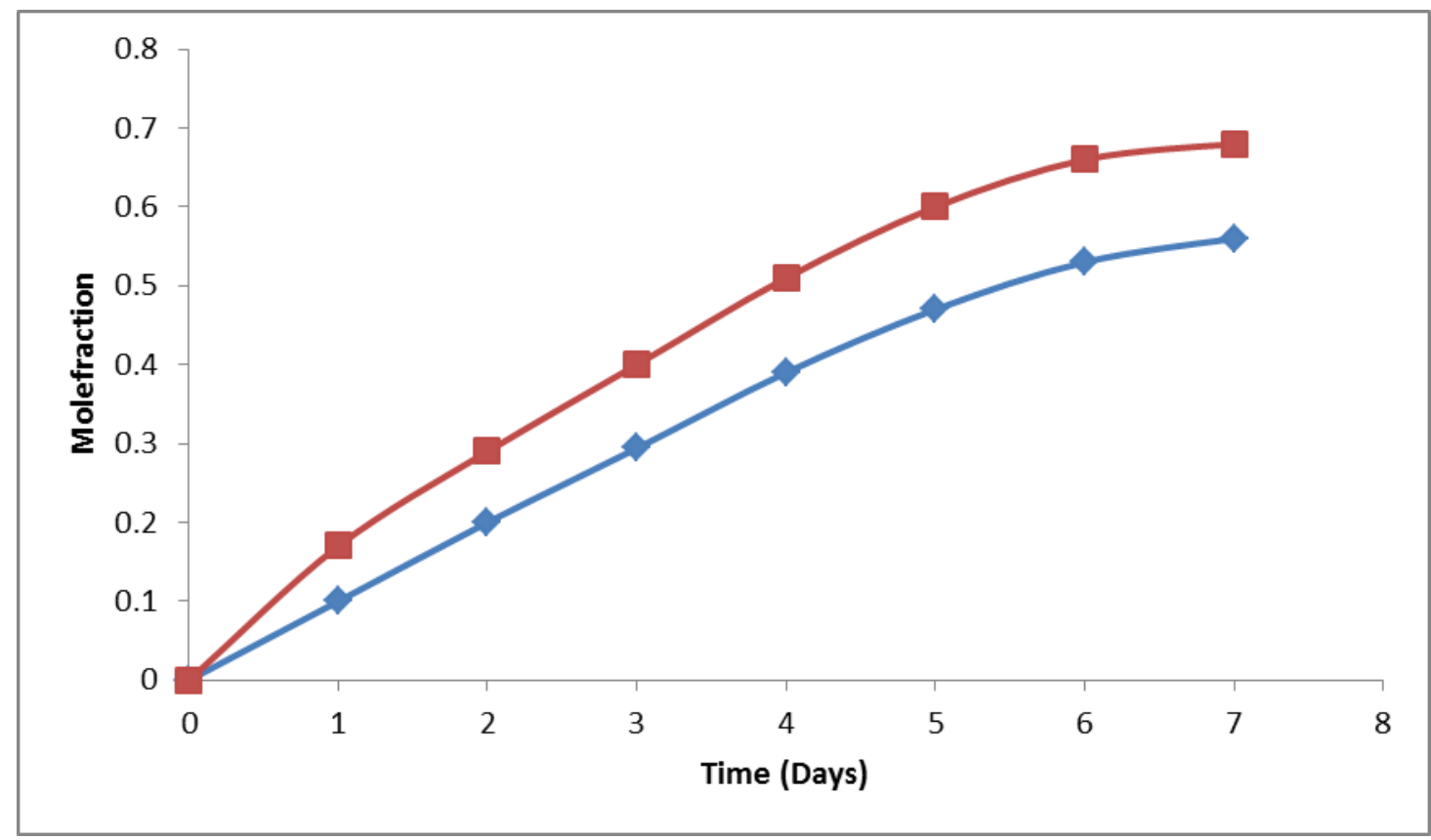

Fig( 3): Controlled Drug Release of Mefenamic Acid in pH 7.4 and 1.1 at $37^{\circ} \mathrm{C}$ 
Heat Flow (W/g)

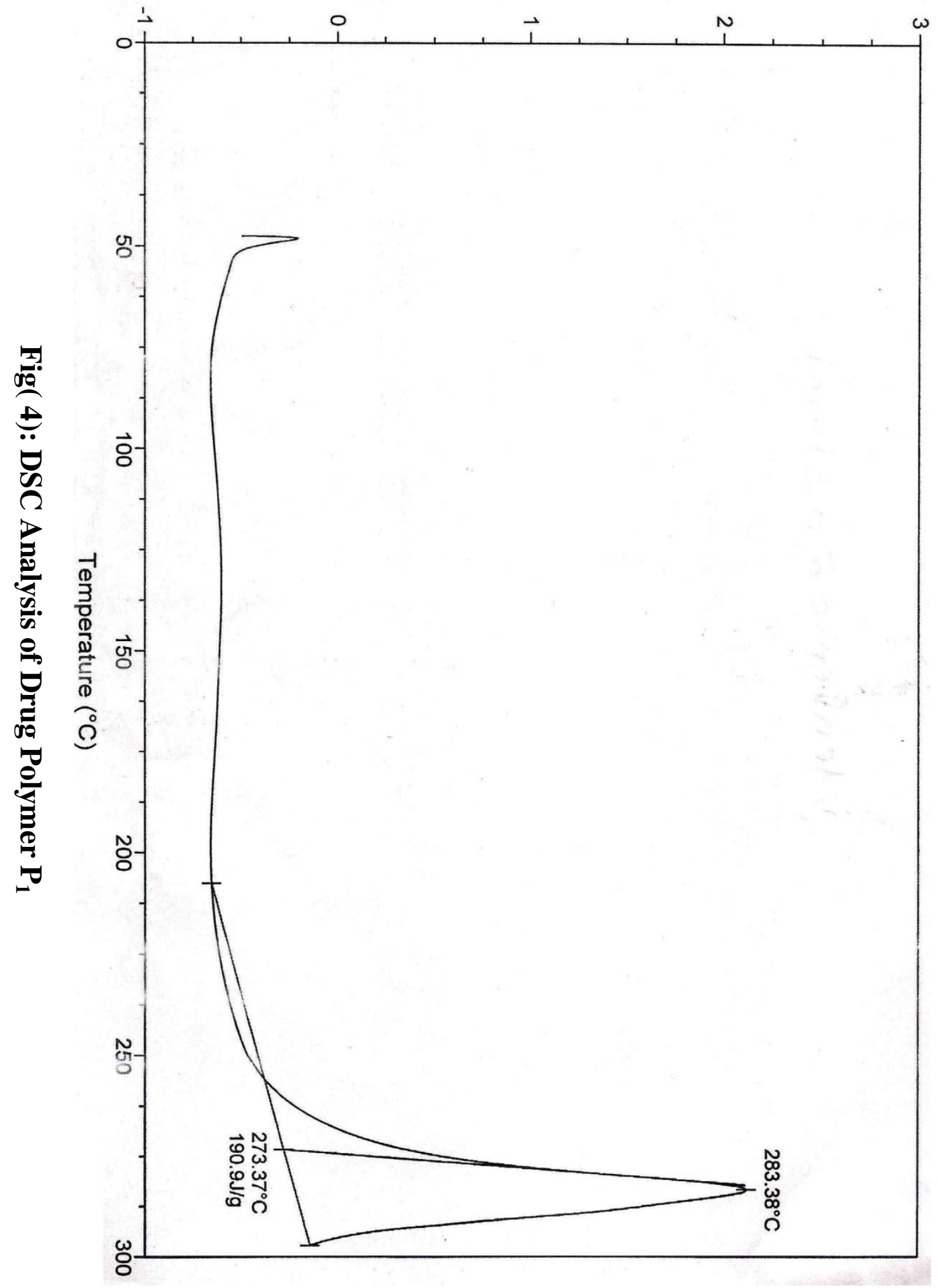




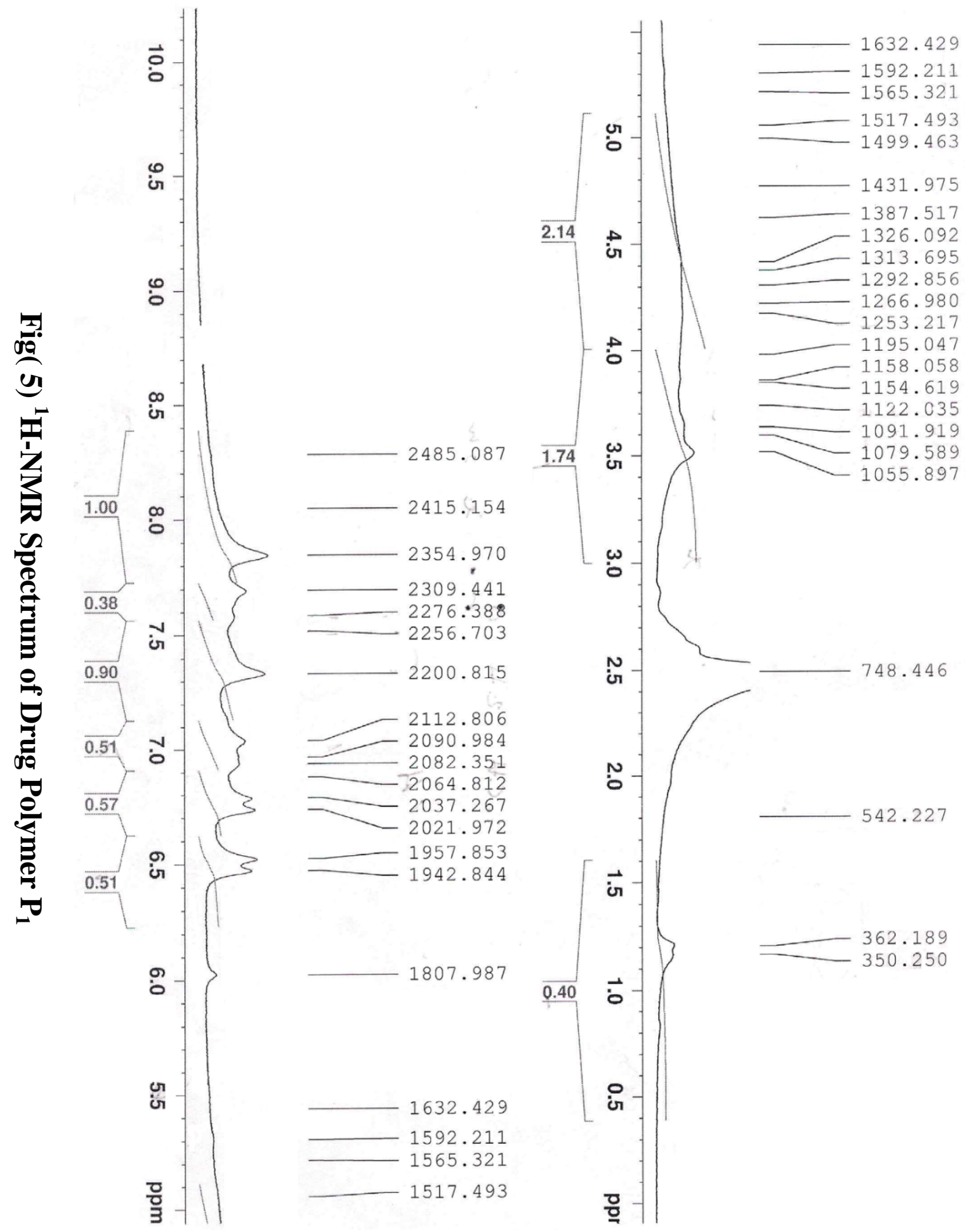


Figure 4 shows the DSC analysis, which recorded the softening point $=28338^{\circ} \mathrm{C}$ and $\Delta H=190.9 \mathrm{~J} / \mathrm{g}$ for the prepared drug polymer $\mathrm{P}_{1}$.

Figure 5 shows the ${ }^{1} \mathrm{H}-\mathrm{NMR}$ spectrum, which indicated the signals were observed of the following:

Part 1 indicated the menfenic aromatic rings $86-7.8 \mathrm{ppm}$ included $4 \mathrm{CH}, 4 \mathrm{H}$

and $3 \mathrm{CH}, 3 \mathrm{H}$ d.d. and $2 \mathrm{CH}_{3}$ s. at $2.5 \mathrm{ppm}$, the $\mathrm{NH}$, s. signal was observed at $4.5 \mathrm{ppm}$.

Part 2 included $5 \mathrm{CH}-\mathrm{O} 5 \mathrm{H}$ d-d and $\mathrm{CH}_{2}-\mathrm{O} 2 \mathrm{H}$ d. (83.5-4.0)ppm and some unreacted $-\mathrm{OH}$ group at $\delta 4.5 \mathrm{ppm}$ as a broad signal.

\section{References}

1. Gebelein C. G. and Koblitz F. F. 1981. Biomedical and Dental Applications of Polymers, J. Polym. Sci. and Tech. Plemm. Press, New York, 14(14).

2. Khaled T. and Jagdish S., 2007 "Smart Polymers Based Delivery Systems for Peptide and Protein", Resent Patents on Drug Delivery and Formulation I, :56-71.

3. Rang H. P., Fale M. M. and Ritter U. J1995. Controlled Release", $3^{\text {rd }}$ Ed., Churchill Livingstone, New York.

4. Luten J., Nostrum C., Smedt S. and Hennink W., 2008. Biodegradable Polymers as nonVital Carriers for Plamid Delivery. J. Cont. Rel., 12:97-110,.

5. Black J., 1981. Biological Performance of Materials. Marcel
Dekken Inc., New York, $3^{\text {rd }}$ Ed. :36 ,.

6. Elvira C., Mano J. F., Roman J. S. and Reis R. L. 2002. Starch-Based Biodegradable Hydrolysis with Potential Biomedical Applications as Drug Delivery Systems. Biomaterials, 23:1955-66.

7. Baipai S. K. and Sing S2006. Analysis of Swelling Behavior of Polymer. React. Funct. Polym., 66 :431-400.

8. Pringshwim T., Davenport W. and DodickD. 2008. Acute Treatment and Prevention of Menstrually Related Migraine Headaches Evidence Baced Review. Neurology, 70(17):1555-1563.

9. National Institutes of Health Side Effect of Mefenamic Acid. 2012. ,11(12):1706-1711.

10. Trinus F., Mokhort N., Yagupol L., Fadeicheva A., Danilenko V. and Ryabukha T., 2006. Pharm. Chem. J., 11(12).

11. Prodelius P. and Vandamme E. J. 1987. Immobilized Cells Systems in Biotechnology, A Comprehensive Treatise in 8 Volumes, 7a :405.

12. Powell L. W., 1990. Immobilized Biocatalyst Technology, E1 Sevier Applied Science, London, :369.

13. Walish P. K. and Malone D. M., 1995. Cell Growth, Biotechnical Adv., 13(1):13-43. 


$$
\text { دراسة حيوية لبوليمر المفيناميت ــ النشا كنظام دوائي جديد }
$$

** أسبل قاسم محمد حسن

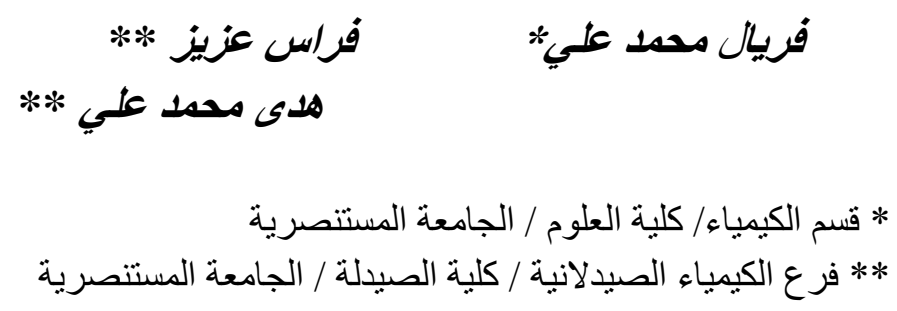

* قسم الكيمياء/ كلية العلوم / الجامعة المستنصرية ** فرع الكيمياء الصيدلانية / كلية الصيللة / الجامعة المستنصرية

الخلاصة:

تم أسترة حامض المفينامك مع النشا بنسبة مولية [1:1] كتعويض دواء على بوليمر طبيعي لغرض إطالة فترة

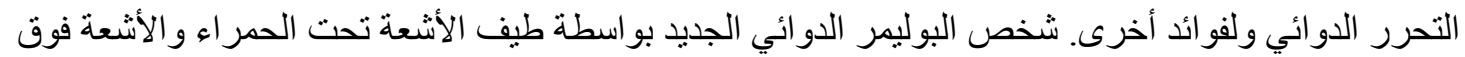

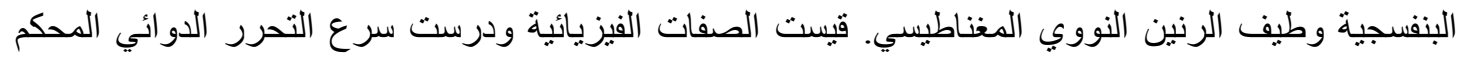

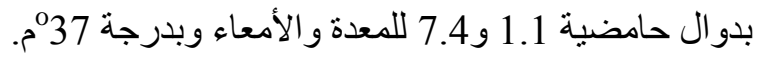

